\title{
Organizing the activity of the family doctor's office in the epidemiological context of the new coronavirus
}

\author{
Organizarea activităţii cabinetului medicului de familie în contextul epidemiologic \\ al noului coronavirus
}

\author{
Adriana TICĂRĂU ${ }^{1,2}$, Mihaela Adela IANCU ${ }^{1,2}$, Dumitru MATEI $\left.\right|^{1,3}$ \\ ${ }^{1}$ Universitatea de Medicină şi Farmacie „Carol Davila“, Bucureşti, România \\ ${ }^{2}$ Cabinet Medical Individual, Bucureşti, România \\ ${ }^{3}$ Institutul Național pentru Sănătatea Mamei şi Copilului „Alessandrescu-Rusescu“, Bucureşti, România
}

\begin{abstract}
The pandemic declared in March 2020 by the World Health Organization has hampered all medical systems around the world, regardless of their endowment, organization or financial strength, forcing medical staff, ministries of health and last but not least, governments, to take action to combat the spread of the new coronavirus called SARS-CoV-2. Among them, the family doctors' offices that make the first contact with the patient had to adopt specific protection measures, both for the medical and auxiliary staff and for the patients, establishing in a short time clear objectives for the operation and organization of the consultation office, like triage, protective equipment and safety for those involved.
\end{abstract}

Keywords: SARS-CoV-2, COVID-19, family medicine, organization, protection measures

REZUMAT -
Pandemia declarată în martie 2020 de către Organizația Mondială a Sănătății a pus în dificultate toate sis-
temele medicale din întreaga lume, indiferent de dotarea, organizarea sau puterea financiară a acestora, obli-
gând personalul medical, ministerele sănătății şi, nu în ultimul rând, guvernele, să ia măsuri urgente de
combatere a răspândirii noului coronavirus denumit SARS-CoV-2. Printre acestea, şi cabinetele medicilor de
familie, care realizează primul contact cu pacientul, au fost nevoite să adopte măsuri specifice de protecție, atât
a personalului medical şi auxiliar, cât şi a pacienților, stabilind intr-un timp scurt obiective clare de functiona-
re şi organizare a cabinetului privind consultul, triajul, echipamentele de protecție şi siguranța celor implicați.

Cuvinte cheie: SARS-CoV-2, COVID-19, medicină de familie, organizare, măsuri de protecție

\section{INTRODUCERE}

Cu toată dezvoltarea pe care a cunoscut-o medicina, epidemia în general, indiferent de agentul cauza- tor, ne va aminti de fiecare dată că natura, în ciuda celor mai mari eforturi ale noastre, a fost și va rămâne dirijorul principal al orchestrei din care face parte și omenirea. Încă din cele mai îndepărtate timpuri, au 
existat încercări de a preveni bolile contagioase cu mortalitate ridicată, cum este variola, descrisă încă din antichitate. Însă inocularea copilului James Phipps cu vaccin antivariolic, la 14 mai 1796, de către medicul generalist englez Edward Jenner a deschis cea mai importantă eră în lupta cu microbii. Trebuie menționată și lucrarea sa de popularizare a științei „Igiena sau arta de a conserva viața“, pentru că, fără aceste două considerente, vaccinul și igiena, lupta noastră împotriva epidemiilor este o luptă din start pierdută [1].

Astfel, în noul context epidemiologic în care ne aflăm de la sfârșitul anului trecut, al răspândirii SARSCoV-2, cu plecare din Wuhan, China, pe tot mapamondul și în condițiile în care încă nu există un vaccin, singura armă pe care o avem în acest moment în lupta cu acest virus este prevenția.

\section{DATE EPIDEMIOLOGICE}

Pentru a putea preveni trebuie întâi să înțelegem modul de transmitere, viabilitatea virusului în mediul înconjurător, tipul de suprafețe ce pot fi contaminate. Astfel, studiile au demonstrat că dacă la începutul focarului a fost identificată o asociere cu o piață din Wuhan unde se vindeau animale vii, ulterior, pe măsură ce focarul a luat amploare, răspândirea de la persoană la persoană a devenit principalul mod de transmitere [2].

Dacă SARS-CoV-2 poate fi transmis pe cale aeriană (prin particule mai mici decât picăturile care rămân în aer în timp și distanță) în condiții naturale a fost o problemă controversată. Un studiu a demonstrat că SARSCoV-2 a rămas viabil în aerosolii generați experimental timp de cel puțin trei ore [3]. Alte studii au identificat ARN viral în sistemele de ventilație și în probele de aer ale camerelor de spital ale pacienților cu COVID-19, dar culturile pentru virus viabil nu au fost efectuate în aceste studii [4-6]. Nu este documentată în mod clar transmisia pe cale aeriană pe o distanță mare a noului coronavirus [7], dar alte studii au sugerat că exhalațiile respiratorii care pot avea traiectorii orizontale pot purta virusul până la 2 metri [8].

Cu toate acestea, relevanța directă a acestor studii despre epidemiologia COVID-19 și implicațiile lor clinice nu sunt clare. Luând în considerare incertitudinea actuală cu privire la mecanismele de transmitere, recomandările generale privind prevenția transmiterii virusului pe cale aeriană sunt cele universale, mai ales atunci când sunt necesare procedurile generatoare de aerosoli.

O altă sursă posibilă de infectare este reprezentată de suprafețe, dar nu se știe cu certitudine despre SARS-CoV-2 cât timp poate persista pe suprafețe [9], însă s-a dovedit că lumina solară simulată (UVB) inactivează virusul in aproximativ 15-20 minute, durata per- sistenței virusului viabil pe suprafețe depinzând de umiditate, de tipul de suprafață, temperatura din mediul înconjurător și de cantitatea de virusuri [10].

\section{ORGANIZAREA ACTIVITǍȚII CABINETULUI}

Activitățile obișnuite ale unităților sanitare, fie ele cabinete individuale, grupate în ambulatorii, fie spitale, au fost nevoite să apeleze la noi norme de combatere a răspândirii sau contaminării cu noul virus, acțiune ce a trebuit să fie implementată într-un timp scurt, inițial fără resursele specifice (echipamente de protecție, dezinfectanți, norme) și, în același timp, să stabilească obiectivele prioritare ce se impun:

\section{Identificarea imediată a cazurilor probabile de îmbolnăvire}

Prima măsură pe care am luat-o în cadrul policlinicii în care lucrez și care cuprinde numai cabinete medicale individuale de medicină de familie, patru la parter și patru la etaj, a fost să asigurăm un triaj al pacienților întâi telefonic, și apoi la intrarea în policlinică, în curtea acesteia, unde am montat un cort pentru triaj. Au fost acceptați în incinta policlinicii numai pacienții programați sau urgențele. Fiecare pacient a primit un chestionar pe care l-a completat pe proprie răspundere, răspunzând la întrebări referitoare la eventualul contact sau călătorie pe care au avut-o în ultima perioadă în zonele afectate de SARS-CoV-2. Toți pacienții care nu aveau măști au primit o mască din fondurile policlinicii. Fiecare pacient a fost termoscanat și îndrumat către dispozitivul cu dezinfectant. Pacienții suspecți de infectare cu SARS-CoV-2, conform definiției de caz, depistați telefonic, au fost direcționați către DSP sau, în cazul celor suspectați/depistați la cabinet, direcționați către 112. Definiția de caz, element în dinamică, a fost zilnic urmărită.

\section{Reducerea riscurilor de transmitere a infecției în rândul pacienților şi al personalului medical şi auxiliar - măsuri specifice}

Achiziționarea echipamentelor de protecție (măști, halate de unică folosință, bonete, botoși, viziere) și a cantității necesare de dezinfectante a fost la început o provocare pe care am depășit-o în scurt timp, reușind să aprovizionăm și să utilăm policlinica cu resursele necesare. A fost instruit personalul medical (asistente) și auxiliar despre prevenirea infecției COVID-19, au fost distribuite materiale de informare pentru pacienți, atât în punctul de triaj, cât și în sala de așteptare, cabinete, grupuri sanitare. S-a luat legătura cu firma colectoare a deșeurilor biologice cu care avem contract și am comunicat faptul că că va fi necesară o frecvență mai mare a ridicării acestora de la sediul po- 
liclinicii. Personalul responsabil cu curățenia a fost instruit să aplice o dată la 1 oră metodele de dezinfecție a suprafețelor, podelelor, clanțelor și a mobilierului din sala de așteptare și cabinete. Recomandăm, de asemenea, achiziționarea unei lămpi UV cu care dezinfectăm cabinetul după plecarea unui pacient posibil infectat, a anexelor (vestiar, grupuri sanitare, sală de așteptare) sau chiar a costumului pe care îl purtăm sub halatul de unică folosință. În acest sens, am stabilit pentru fiecare zi a săptămânii un set de uniformă medicală de o anumită culoare pentru a nu le confunda (de exemplu luni, culoarea roșie, marți - galben, și tot așa), pe care la sfârșitul programului am sterilizat-o cu ajutorul lămpii UV, urmând a fi purtată din nou peste șapte zile, reducând astfel riscul de contaminare. Uniformele medicale sub nicio formă nu vor fi duse acasă pentru a fi spălate, ci vor fi curățate în unități specializate. Circuitul pacienților, acolo unde este posibil, este bine să fie circular, în sensul în care calea de ieșire din policlinică trebuie să fie diferită de calea de acces. S-a recomandat eliminarea din cabinet a mobilierului, dosarelor și a altor resurse inutile ce se pot contamina $[11,12]$.

De asemenea, trebuie ținut cont de ordinea corectă de echipare și dezechipare conform recomandărilor [14] în vigoare. Astfel, echipamentul de protecție se pune în ordine - halat (cu mâneci lungi!) sau combinezon, mască, ochelari de protecție sau vizieră, mănuși - și se scoate corect în ordine - mănuși, ochelari de protecție sau vizieră, halat, mască -, cu dezinfectarea corespunzătoare a mâinilor.

\section{Menținerea activității cabinetului în condiții de siguranță}

Se poate face prin limitarea prezentării pacienților la cabinet în acele situații în care pacienții pot fi îndrumați din punct de vedere medical telefonic sau prin alte mijloace de comunicație așa cum sunt platformele de socializare facebook, whatsapp sau chiar e-mail. în cazul în care prezentarea la cabinet este necesară, vor fi luate toate măsurile de precauție discutate anterior $[13,14]$.

\section{Temporizarea solicitărilor suplimentare ale personalului medical}

Suprasolicitarea personalului medical ca urmare a pandemiei poate fi luată în considerare ținând cont de factorii de risc care pot induce acest sindrom și care cuprind suprasolicitare profesională, impactul cu o pandemie/infodemie, impactul unei boli noi cu mecanism patologic complex, fără tratament, lipsa vaccinului, achiziția echipamentului de protecție, echiparea/ dezechiparea în condiții de securitate, procentul mare de infectări ale personalului medical, avalanșa de informații, riscul real de îmbolnăvire a familiei, conflictele de durată, profesii care implică un grad mare de responsabilitate.

Astfel, pentru a putea diminua efectele negative psihologice ale noului context epidemiologic, este recomandat ca medicul să beneficieze de o pauză la prânz, de pauză de știri, de informare din surse competente, să limiteze interacțiunile online doar la cele de natură profesională sau de recreere, să micșoreze durata de lucru atunci când este posibil, să stabilească un interval de timp concret pentru pacienți, să apeleze la tehnici de reducere a stresului, să țină cont de timpul liber și de timpul de refacere și odihnă, limitarea consultațiilor dacă nu sunt necesare, timp petrecut cu familia, prietenii, animalele de companie.

\section{Surse de informare}

Un alt punct important în gestionarea activității este reprezentat de sursa de informare, care, pe lângă site-urile medicale competente, trebuie să le cuprindă și pe cele ale Ministerului Sănătății (http://www. ms.ro), Centrului Național de Supraveghere și Control al Bolilor Transmisibile (http://www.cnscbt.ro), Departamentului pentru Situații de Urgență (https://www. facebook.com/departamenturgente), Organizației Mondiale a Sănătății România (https://www.facebook. com/OMSRomania), Organizației Mondiale a Sănătății (https://www.facebook.com/WHO), Centrului European pentru Controlul și Prevenția Bolilor (https:// www.ecdc.europa.eu/en), Centrului pentru Prevenția și Controlul Bolilor din SUA (https://www.cdc.gov) [15].

\section{CONCLUZII}

Pentru o bună organizare a cabinetului medical individual, așa cum este cabinetul medicului de familie, dar nu numai, îndeplinirea obiectivelor propuse stă la baza unei funcționări în siguranță epidemiologică în sprijinul atât al pacienților, cât și al personalului medical și auxiliar, fără a uita însă că suntem la început de drum în lupta cu SARS-CoV-2 și că, în lipsa unui vaccin, starea de alertă a personalului medical trebuie să rămână principala preocupare din noul context epidemiologic, după, bineînțeles, preocuparea pe care noi, medicii, o avem față de sănătatea pacienților noștri.

\section{Mențiune}

Toți autorii au avut o contribuție egală în realizarea acestui articol. 


\section{BIBLIOGRAFIE}

1. Dr. Marius Mărginean: Edward Jenner 200 ani de la prima vaccinare antivariolică. Medicina familiei nr.11-12, 1996.

2. World Health Organization. Novel coronavirus situation report -2. January 22, 2020. https://www.who.int/docs/defaultsource/coronaviruse/situationreports/20200122-sitrep-2-2019-ncov.pdf (Accessed on January 23, 2020).

3. van Doremalen N, Bushmaker T, Morris $\mathrm{DH}$, et al. Aerosol and Surface Stability of SARS-CoV-2 as Compared with SARSCoV-1. N Engl J Med. 2020;382:1564.

4. Ong SWX, Tan YK, Chia PY et al. Air, Surface Environmental, and Personal Protective Equipment Contamination by Severe Acute Respiratory Syndrome Coronavirus 2 (SARS-CoV-2) From a Symptomatic Patient. JAMA 2020.
5. Guo ZD, Wang ZY, Zhang SF et al. Aerosol and Surface Distribution of Severe Acute Respiratory Syndrome Coronavirus 2 in Hospital Wards, Wuhan, China, 2020. Emerg Infect Dis. 2020;26:1583.

6. Liu Y, Ning Z, Chen Y et al. Aerodynamic analysis of SARS-CoV-2 in two Wuhan hospitals. Nature 2020;582:557.

7. Lu J, Gu J, Li K et al. COVID-19 Outbreak Associated with Air Conditioning in Restaurant, Guangzhou, China, 2020. Emerg Infect Dis 2020;26:1628.

8. Bourouiba L. Turbulent Gas Clouds and Respiratory Pathogen Emissions: Potential Implications for Reducing Transmission of COVID-19. JAMA 2020.

9. van Doremalen N, Bushmaker T, Morris DH et al. Aerosol and Surface Stability of SARS-CoV-2 as Compared with SARS-
CoV-1. N Engl J Med 2020;382:1564.

10. Ratnesar-Shumate S, Williams G, Green B et al. Simulated Sunlight Rapidly Inactivates SARS-CoV-2 on Surfaces. J Infect Dis 2020.

11. https://insp.gov.ro/sites/Biocide/public_html/ Documente/Biocide/Norma_tehnica_ din_19_08_2016.pdf.

12. http://www.cnscbt.ro/index.php/informatiipentru-personalul-medico-sanitar/1487reguli-de-urmat-in-igiena-mainilor-pentrupersonalul-medical-care-ingrijestepersoanele-suspecte-sau-confirmate-cuinfectie-cu-noul- coronavirus.

13. http://www.cnscbt.ro/index.php/metodologii/ infectia-2019-cu-ncov.

14. http://www.pmfb.ro/storage/documents/ recomandaripentrupersonalulmedical.pdf.

15. http://respirogrup.ro/resurse/recomandaricovid-19-pentru-cabinete-mf. 